\title{
Effects of feeding Aloe Vera Leaves Powder on Performance, Carcass and Immune Traits of Broiler Chickens
}

\author{
Seham M. Mohamed*, Wafaa. A. El-Eraky and Mahmoud. F. Al- Gamal \\ Nutrition and Clinical Nutrition Department, Faculty of Veterinary Medicine, Zagazig \\ University, 44511, Egypt
}

\begin{abstract}
The current study was carried out to study the effect of dietary supplementation with Aloe Vera leaves powder (AVLP) as natural feed additives on growth performance, carcass characteristics and immune response of broiler chickens. Ross unsexed one day old $(75 \mathrm{gm})$ broiler chicks $(n=90)$ were randomly divided into five experimental groups; each group with three replicates (18 chicks/group; 6 chicks/replicate). Diets supplemented with AVLP at rates of 0, 1.5, 2.0 and $2.5 \%$ and the last group supplemented with antibiotic (Oxytetracyclin $1 \mathrm{~g} / \mathrm{kg}$ diet) for 42 days. Body weights and feed residues were monitored weekly. At the end of the trial, three birds/group were euthanized and then blood samples were collected, moreover carcass dressing and visceral organs were collected and weighed. Results revealed that AVLP had no significant $(\mathrm{P}>0.05)$ effects on growth performance of broiler chicken. All treated groups showed non-significant $(\mathrm{P}>0.05)$ effect on internal organ weights and carcass traits. Diets supplemented with 1.5, 2.0 and $2.5 \%$ of AVLP stimulate the immunity by increasing the phagocytic capacity and antibody titre against Newcastle disease virus when compared with the control group. These results indicated that addition of AVLP in broiler chicken's diets has no adverse effects on growth performance beside it improves the humoral and the cellular immunity.
\end{abstract}

Keywords: Aloe Vera Leaves Powder, Broiler, Performance, Carcass, Immunity.

\section{Introduction}

Antibiotic growth promoters are helpful in improvement the growth performance and feed conversion ratio in poultry [1]. However, constant treatment of poultry by antibiotic may result in residues of these substances in poultry products and bacterial resistance against treatments in human body [2]. Many studies were carried out on using feed additives, including herbs as alternatives to antibiotics [3]. Aloe Vera is one of the most important medicinal plants that have many biologically active compounds. Many studies revealed the antibacterial, antiseptic, anti-inflammatory and immune-modulator effect of Aloe Vera [4] so it can be used as a replacement for antibiotic growth promoter.

Supplementation of Aloe Vera to substitute antibiotic growth promoter give a higher body weight gain and feed intake and better feed conversion [5]. Aloe Vera leaves in broiler chick's diet especially at level of $1 \%$ and $2 \%$ of feed, improved immunity by increase geometric means of HI titres against NDV [6]. Aqueous extract of Aloe gel had improved the dressing weight and intestinal weight, while abdominal fat deposition, breast, thigh weight, gizzard, liver and heart weight of the broilers was not affected [7]. The overall goals of the present trial were to investigate the effect of dietary supplementation with Aloe Vera leaves powder (AVLP) as an alternative to antibiotics on growth performance, carcass characteristics and immune response of broiler chickens.

\section{Material and Methods}

\section{Preparation of Aloe Vera leaves powder [AVLP]}

The whole fresh and matured Aloe Vera leaves were collected from local market, washed under tape water, dried in hot air oven at $50^{\circ} \mathrm{C}$ followed by $105^{\circ} \mathrm{C}$ until obtained constant weight then ground using manual grinder into fine particles and consequently added to the ration.

\section{Animals, feeding and experimental design}

In this study, 90 one day old (75 gm) Ross unsexed broiler chicks were obtained from a commercial hatchery. The birds were weighed and randomly divided into 5 groups with 3 replicates per group (18 chicks/group; 6 chicks /replicate). The birds were housed in separated clean pens and kept under continuous lighting system with suitable temperature till the experimental end. The basal diet was formulated to meet the nutrient requirements 
according to NRC [8] as in starter period (0-2 wks; CP 23.07\% and ME $3198 \mathrm{kcal} / \mathrm{kg}$ diet); grower period (2-4 wks; CP 20.10\% and ME $3201 \mathrm{kcal} / \mathrm{kg}$ diet) and finisher period (4-6 wks; CP $18.5 \%$ and ME $3204.40 \mathrm{kcal} / \mathrm{kg}$ diet). The diets were offered in mash form. Feed and water were provided ad-libitum. The experimental groups supplemented with AVLP at a rate of $0,1.5,2.0$ and $2.5 \%$ and the last group supplemented with antibiotic (Oxytetracyclin $1 \mathrm{~g} / \mathrm{kg}$ diet) for 42 days. Experimental feedstuffs and diets were analyzed for nutrients (DM, CP and EE) [9].

Table 1: Composition and chemical analysis of the experimental diets

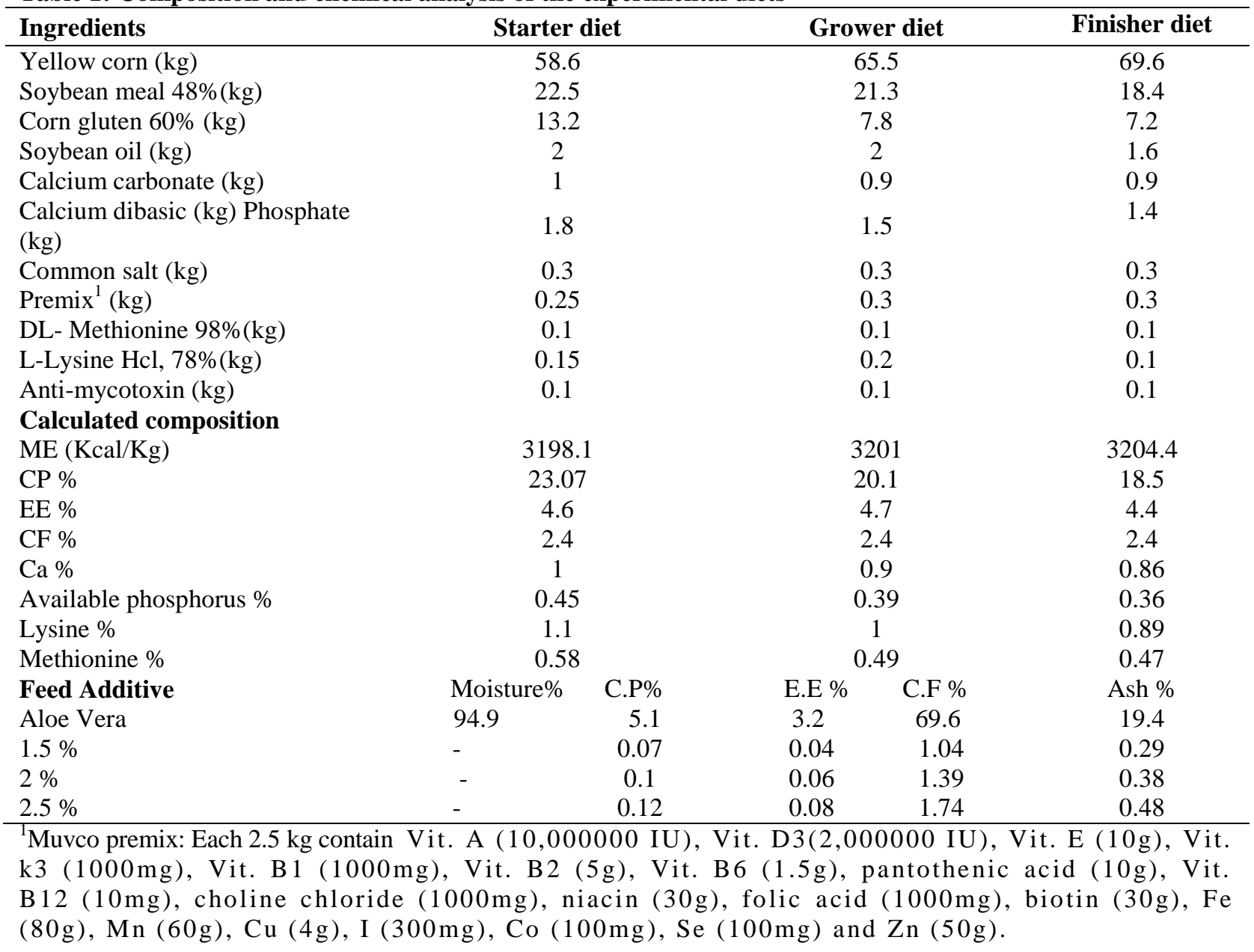

\section{Growth performance and carcass traits}

Individual chicks were weighed weekly to determine the body weight (BW), also amount of feed intake (FI). Body weight gain (BWG) and feed conversion ratio (FCR) were calculated [10]. At the end of the experiment (42 days), 3 birds from each group were selected, fasted overnight, weighed then slaughtered by sharp knife. After complete bleeding, plucking the feather, evisceration and finally weighed the carcass to estimate the dressing percentage in which the head, neck, feet and lower wing were removed. The intestine, liver, gizzard, heart, spleen and abdominal fat were weighed and expressed as $\%$ of live body weight.

\section{Immunological parameters}

\section{Assay procedure for humoral immunity}

The humoral immunity was measured using the haemagglutination (HA) and haemagglutination inhibition tests (HI) carried out according to Anon [11]. HI test carried out using the micro technique beta procedure (constant virus plus diluted serum) [12]. 
Assay procedure for cellular immunity (phagocytic assay)

Blood was collected from chickens [3-5 mL blood] into heparinized tubes. The tubes opened in the laminar flow hood and pipette blood from each glass tube into a $15 \mathrm{~mL}$ falcon tube. An amount of $10 \mathrm{~mL}$ PBS was placed into each tube [1:2 Blood to PBS]. Overlaying in $2 \mathrm{~mL}$ Ficoll in falcon tube then the diluted blood was added gently on the side of the tube to avoid the distraction of WBCs cells. Centrifugation at $1750 \mathrm{rpm} / 10 \mathrm{~min}$ till have a gradient i.e. cells are in layers. Resultant layers were approximately from top to bottom: Plasma - platelets - PBMC (peripheral blood mononuclear cells)- Ficoll -red blood cells. The supernatant plasma was discarded. Then Careful aspiration of buffy coat with PBMC's and transferring it to new tube were done. Enough PBS was added to the PBMC and Spin at $1500 \mathrm{rpm}$ for 10 minutes. The supernatant was decanted and the cells washed once again with PBS. The solution discarded using diagonal position and RPMI 1640 media with antibiotics to the remained cell suspension. From the mixture of cell suspension and RPMI $1640,1 \mathrm{~mL}$ was taken and put in each well. Microbial suspension of candida was prepared by taking 1 colony from candida mixed with 1 mL PBS in sterile test tube, mixed thoroughly and $10 \mathrm{uL}$ from the candida suspension was added to each well, the plate was mixed well using 8 figure position. The cultured plates kept in $\mathrm{Co} 2$ incubator for about $30 \mathrm{~min}$, then were examined microscopically [13].

\section{Statistical analysis}

All the data analyzed using one way analysis of variance ANOVA using SAS [14]. The significant mean differences were done with Duncan's multiple range tests. The significance based on $\mathrm{P}<0.05$ level of probability.

\section{Results and Discussion \\ Growth performance and carcass quality}

Growth performance of birds fed the experimental diets was presented in Table (2). The dietary treatments with AVLP had no significant $(\mathrm{P}>0.05)$ difference in final body weight, body weight gain and total feed intake when compared with the control group. Group fed diet supplemented with antibiotic (Oxytetracyclin) $1 \mathrm{~g} / \mathrm{kg}$ diet showed significant $(\mathrm{P}<0.05)$ higher FCR than other groups. The growth performance of birds fed diets contained AVLP performance results were alike those of Mehala and Moorthy [15], who reported that there was no difference in body weight, body weight gain and feed consumption between broiler groups fed diets supplemented with Aloe Vera and Curcuma longa and their combinations. In the same line Amaechi and Iheanetu [5], investigated the dietary supplementation of Aloe Vera at rate of $0.5, \quad 1.0$ and $1.5 \%$ and antibiotic (Enramycin). They reported significant $(\mathrm{P}<$ 0.05) higher FCR and lower feed efficiency, while no significant changes of body weight gain and feed intake when compared with the control group. The obtained results disagreed with Khan et al. [6], who studied the effect of using Aloe Vera leaves in broiler chicks' ration by 1 and $2 \%$. They detected an improvement in weight gain with better feed intake and feed efficiency than those fed diets without Aloe Vera leaves. 
Table 2: Effect of dietary supplementation with Aloe Vera leaves powder (AVLP) on the growth performance of broiler chicks

\begin{tabular}{lccccc}
\hline Parameters & \multicolumn{5}{c}{ Experimental diets } \\
\cline { 2 - 6 } & Control & $\mathbf{1 . 5 \%}$ AVLP & 2\% AVLP & 2.5\% AVLP & $\begin{array}{c}\text { Oxytetracyclin } \\
\text { 1gm/kg diet }\end{array}$ \\
\hline $\begin{array}{l}\text { Initial body } \\
\text { weight(g) }\end{array}$ & 75 & 75 & 75 & 75 & 75 \\
$\begin{array}{l}\text { Final body } \\
\text { weight (g) }\end{array}$ & $2991.66 \pm 65.84$ & $2751.66 \pm 158.91$ & $2991.66 \pm 186.28$ & $2741.66 \pm 79.49$ & $2935.00 \pm$ \\
$\begin{array}{l}\text { Absolute weight } \\
\text { gain (g) }\end{array}$ & $2916.66 \pm 65.84$ & $2676.66 \pm 158.91$ & $2916.66 \pm 186.28$ & $2666.66 \pm 79.49$ & $2860 \pm 184.54$ \\
$\begin{array}{l}\text { Total feed } \\
\text { consumption, g }\end{array}$ & $4409.22 \pm 146.98^{\mathrm{ab}}$ & $3721.52 \pm 254.26^{\mathrm{b}}$ & $4352.91 \pm 281.57^{\mathrm{ab}}$ & $4038.11 \pm 81.66^{\mathrm{b}}$ & $4914.72 \pm 343.13$ \\
$\begin{array}{l}\text { Feed conversion } \\
\text { ratio }\end{array}$ & $1.51 \pm 0.08^{\mathrm{b}}$ & $1.38 \pm 0.01^{\mathrm{b}}$ & $1.49 \pm 0.03^{\mathrm{b}}$ & $1.51 \pm 0.03^{\mathrm{b}}$ & $1.71 \pm 0.05^{\mathrm{a}}$ \\
\hline
\end{tabular}

The results of carcass yield were presented in Table (3). There was non-significant $(\mathrm{P}>0.05)$ differences in the carcass dressing, intestine, liver, gizzard, heart, spleen and abdominal fat percentages among the experimental groups. The obtained results agreed with Mehala and Moorthy findings [15], who evaluated the inclusion of Aloe Vera and Curcuma longa and its combinations and found no significant difference in carcass yields. However, our results differed with those of Iheanetu [5], who investigated the dietary supplementation of Aloe Vera at rate of $0.5,1.0$ and $1.5 \%$ and group of antibiotic Enramycin0 and reported that the antibiotic group showed better dressing weight than the Aloe Vera powder and the control groups.

Table 3: Effect of dietary supplementation with Aloe Vera leaves powder (AVLP) on carcass traits of broiler chicks (Means \pm SE)

\begin{tabular}{lccccc}
\hline Parameters & \multicolumn{3}{c}{ Experimental diets } \\
\cline { 2 - 6 } & Control & $\mathbf{1 . 5 \%}$ AVLP & $\mathbf{2 \%}$ AVLP & $\mathbf{2 . 5 \%}$ AVLP & $\begin{array}{c}\text { Oxytetracycline } \\
\text { 1 gm/kg diet }\end{array}$ \\
\hline Dressing, \% & $80.94 \pm 6.69$ & $73.41 \pm 0.49$ & $72.6 \pm 1.22$ & $72.01 \pm 0.88$ & $73.59 \pm 0.74$ \\
Intestine, \%* & $4.89 \pm 0.34$ & $5.91 \pm 0.2$ & $5.73 \pm 0.47$ & $5.52 \pm 0.79$ & $5.28 \pm 0.39$ \\
Liver, \% & $2.30 \pm 0.20$ & $2.07 \pm 0.1$ & $2.39 \pm 0.17$ & $2.12 \pm 0.08$ & $2.36 \pm 0.18$ \\
Gizzard, \% & $2.09 \pm 0.16$ & $2.38 \pm 0.21$ & $2.15 \pm 0.18$ & $2.17 \pm 0.34$ & $2.26 \pm 0.16$ \\
Heart, \% & $0.49 \pm 0.02^{\mathrm{ab}}$ & $0.55 \pm 0.02^{\mathrm{a}}$ & $0.43 \pm 0.02^{\mathrm{b}}$ & $0.53 \pm 0.04^{\mathrm{ab}}$ & $0.48 \pm 0.05^{\mathrm{ab}}$ \\
Spleen, \% & $0.15 \pm 0.01$ & $0.12 \pm 0.02$ & $0.19 \pm 0.01$ & $0.18 \pm 0.03$ & $0.13 \pm 0.03$ \\
Abdominal fat, \% & $0.35 \pm 0.08$ & $0.36 \pm 0.12$ & $0.44 \pm 0.13$ & $0.36 \pm 0.13$ & $0.42 \pm 0.16$ \\
\hline
\end{tabular}

*Intestine \%: the weight from the beginning of duodenum tells the end of rectum that expressed as a percentage of live body weight.

\section{Immunological parameters}

\section{Phagocytic capacity of broiler chicks}

Data of phagocytic percent of broiler chicken were presented in Table (4). The results revealed that no significant $(\mathrm{P}>0.05)$ difference in phagocytic percent among all experimental groups and the control group, while groups fed diet supplemented with 1.5 and $2.5 \%$ ALP showed significant $(\mathrm{P}<0.05)$ higher phagocytic index when compared with the experimental groups. This improvement in immunity due to polysaccharide contained in aloe vera called acemannan which can stimulate both humoral and cellular immunity by increase cytokines and antibodies that enhance the performance of natural killers, $\mathrm{B}$ - and $\mathrm{T}$ lymphocyte. 
Table 4: Effect of dietary supplementation with Aloe Vera leaves powder (AVLP) on phagocytic capacity of broiler chicks (Means \pm SE)

\begin{tabular}{lccccc}
\hline Parameters & \multicolumn{3}{c}{ Experimental diets } \\
\cline { 2 - 6 } & Control & $\mathbf{1 . 5 \%}$ AVLP & $\mathbf{2 \%}$ AVLP & $\mathbf{2 . 5 \%}$ AVLP & $\begin{array}{c}\text { Oxytetracycline } \\
\mathbf{1} \text { gm/kg diet }\end{array}$ \\
\hline Phagocytic, \% & $62.0 \pm 1.15$ & $68.0 \pm 4.05$ & $62.0 \pm 1.15$ & $73.0 \pm 6.02$ & $64.0 \pm 3.05$ \\
Phagocytic index & $4.36 \pm 0.14^{\mathrm{b}}$ & $5.76 \pm 0.3^{\mathrm{a}}$ & $4.46 \pm 0.08^{\mathrm{b}}$ & $5.43 \pm 0.41^{\mathrm{a}}$ & $4.43 \pm 0.18^{\mathrm{b}}$ \\
\hline
\end{tabular}

${ }^{\mathrm{ab}}$ Means in the same row carrying different superscripts were significantly different $(\mathrm{P}<0.05)$.

\section{log antibody of broiler chicks}

In current study, there was no significant $(\mathrm{P}>0.05)$ difference in log antibody GMT between all experimental groups in $1^{\text {st }}, 2^{\text {nd }}, 4^{\text {th }}$ and $5^{\text {th }}$ week, while in $3^{\text {rd }}$ week, groups fed diet supplemented with $2.5 \%$ ALP showed significant $(\mathrm{P}<0.05)$ higher antibody titre against Newcastle disease virus. But, we recorded no significant $(\mathrm{P}>0.05)$ difference in group fed diet supplemented with 2\% ALP when compared with the other experimental groups.

Table 5: Effect of dietary supplementation with Aloe Vera leaves powder (AVLP) on log antibody GMT of broiler chicks (means \pm SE).

\begin{tabular}{|c|c|c|c|c|c|}
\hline \multirow{2}{*}{$\begin{array}{c}\text { Antibody } \\
\text { titer/week }\end{array}$} & \multicolumn{5}{|c|}{ Experimental diets } \\
\hline & Control & $1.5 \%$ AVLP & $2 \%$ AVLP & $2.5 \%$ AVLP & $\begin{array}{l}\text { Oxytetracycline } \\
1 \text { gm/kg diet }\end{array}$ \\
\hline $1^{\text {st }}$ week & $18.66 \pm 7.05$ & $18.66 \pm 7.05$ & $21.33 \pm 5.33$ & $18.66 \pm 7.05$ & $18.66 \pm 7.05$ \\
\hline $2^{\text {nd }}$ week & $8.00 \pm 4.61$ & $5.33 \pm 2.66$ & $16.66 \pm 8.66$ & $17.33 \pm 8.11$ & $9.33 \pm 3.52$ \\
\hline $3^{\text {rd }}$ week & $1.33 \pm 1.33^{\mathrm{b}}$ & $2.66 \pm 1.33^{\mathrm{b}}$ & $12.66 \pm 9.68^{\mathrm{ab}}$ & $34.66 \pm 16.22^{\mathrm{a}}$ & $4.66 \pm 1.76^{\mathrm{b}}$ \\
\hline $4^{\text {th }}$ week & $26.66 \pm 5.33$ & $133.33 \pm 69.33$ & $512.66 \pm 295.02$ & $533.33 \pm 277.33$ & $69.33 \pm 32.44$ \\
\hline $5^{\text {th }}$ week & $25.33 \pm 19.36$ & $53.33 \pm 10.66$ & $133.33 \pm 69.33$ & $202.66 \pm 154.94$ & $174.66 \pm 68.67$ \\
\hline $6^{\text {th }}$ week & $174 \pm 169^{\mathrm{b}}$ & $341.33 \pm 85.33^{\mathrm{ab}}$ & $768 \pm 256^{\mathrm{ab}}$ & $1376 \pm 672^{\mathrm{a}}$ & $213.33 \pm 42.66^{\mathrm{b}}$ \\
\hline
\end{tabular}

${ }^{\mathrm{ab}}$ Means in the same row carrying different superscripts were significantly different $(\mathrm{P}<0.05)$.

At $6^{\text {th }}$ week, groups fed diet supplemented with $2.5 \%$ ALP showed significant $(\mathrm{P}<0.05)$ higher antibody titre against Newcastle disease virus when compared with the control and antibiotic groups and showed non significant $(\mathrm{P}>0.05)$ with other groups. Enhanced humoral immunity can be attributed to polysaccharide contained in Aloe Vera (acemannan). It can increase cytokines and antibodies production. The obtained results were clearly confirmed by Durrani et al. [7], who investigated the effect of aqueous extract of aloe gel and found significantly $(\mathrm{P}<0.05)$ higher serum antibody titer for IBD in group received $15 \mathrm{~mL}$ of aqueous extract of aloe gel/liter of water when compared with the others in broilers. In the same line, Khan et al. [6] determined the effect of using $1 \%$ and $2 \%$ of Aloe Vera leaves and showed that gometric means of HI titres of birds fed on diets containing Aloe Vera leaves were higher than those fed on control in broiler chicks.

\section{Conclusion}

In accordance with the obtained results, dietary supplementation of broiler chickens with Aloe Vera leaves powder, hadn't adverse effects on growth performance, carcass quality and simulated both humoral and cellular body immunity. Thus, the use of these natural feed additives at level of $1.5,2.0$ and $2.5 \%$ in broiler diets is recommended as an immunestimulant.

\section{Conflict of interest}

The authors have no any conflict of interest.

\section{References}

[1] Miles, R.D.; Butcher, G.D.; Henry, P.R. and Littell, R.C. (2006): Effect of 
antibiotic growth promoters on broiler performance, intestinal growth parameters and quantitative morphology. Poult Sci, 85: 476-485.

$\left.{ }^{[}{ }^{\Upsilon}\right]$ Owens, B.; Tucker, L.; Collins, M.A. and McCracken, K.J. (2008): Effects of different feed additives alone or in combination on broiler performance, gut microflora and ileal histology. Brit Poult Sci, 49: 202-212.

[r] Taylor, D.J. (2001): Effects of antimicrobials and their alternatives. Brit Poult Sci, 42: 67-68.

[₹] Moorthy, M.; Saravanan, S.; Mehala, C.; Ravi, S.; Ravikumar, M.; Viswanathan, K. and Edwin, S.C. (2009): Performance of single comb white leghorn layers fed with Aloe vera, Curcuma longa [turmeric] and probiotic. Int J Afr J Poult Sci, 8(8): 775-778.

[0] Amaechi, N. and Iheanetu, E. (2014): Evaluation of dietary supplementation of broiler chicks with different levels of aloe vera as a replacement for antibiotic growth promoter on broiler production in the humid tropics. Inter J Vet Sci, 3(2): 68-73.

[6] Khan, M.J.A.; Khan, S.H.; Naz, S. and Gilani, S.S. (2014): Effect of dietary supplementation of aloe vera leaves on growth performance and immunity of Fayoumi chicks. Pakistan journal of nutrition, 13(4): 191-195.

[7] Durrani, F.R.; Ullah, S.; Chand, N.; Durrani, Z. and Akhtar, S. (2008): Using aqueous extract of aloe gel as anticoccidial and immunostimulant agent in broiler production. Sarhad J Agric, 24(4): 665-670.
[8] National Research Council (NRC) (1994): Nutrition requirements of poultry. $9^{\text {th }}$ Ed., Washington, DC National Academy Press.

[9] AOAC (1984) Association of officials analytical chemists: Official method of analysis. $13^{\text {th }}$ Ed. Washington .D.C. USA.

[10] Wagner, D.D; Furrow, R.D. and Bradley, B.D. (1983): Subchronic toxicity of growth promoters in broilers chickens. Vet Path, (20): 253-359.

[11] Anon (1971): Methods for examination of poultry biologics and identification of avian pathogens. Nat Acad of science, Washington DC.

[12] Allan, W.H. and Gough, R.E. (1974): A standard hem agglutination inhibition test for New castle disease.1-A comparison of macro and micro methods. Vet Rec, 95: 120-123.

[13] Elmowalid, G.A.M.A. (2003): Unmasking the effect of bovine viral diarrhea virus on macrophage inflammatory functions. A dissertation submitted in partial fulfilment of the requirements for the Doctor of Philosophy Major in Biological Sciences, Veterinary Microbiology (Immunology), South Dakota State University. Chapter 2, P. 105-113.

[14] SAS Institute (1985): SAS user's guide. SAS Institue. Inc, Cary, C27513, USA. Institute Carg. N.C.

[15] Mehala, C. and Moorthy, M. (2008): Production Performance of Broilers Fed with Aloe vera and Curcuma longa [Turmeric]. Inter J Poult Sci, 7(9): 852856. 


\section{الملخص العربى \\ تأثير تغذية أوراق نبات الصبار المجفة على الأداء في بداري التسمين

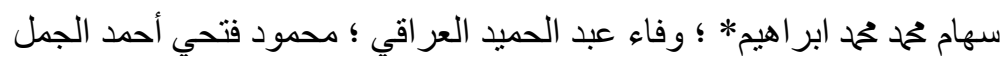

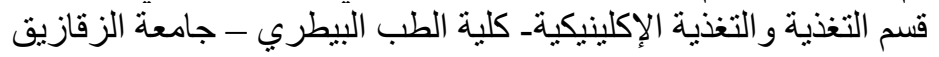

تم اجر اء هذه التجربة لدراسة أثر إضافة مسنويات مختلفة من أوراق نبات الصبار المجففة كإضافات طبيعية للأعلاف كناف

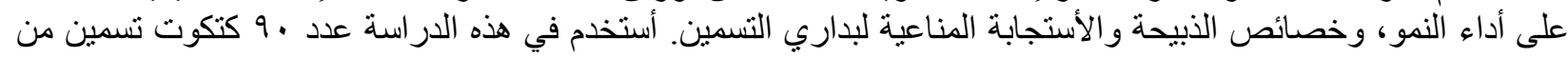

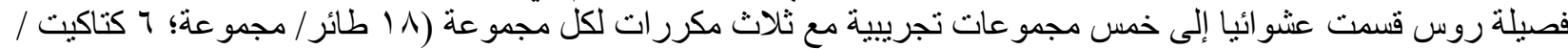

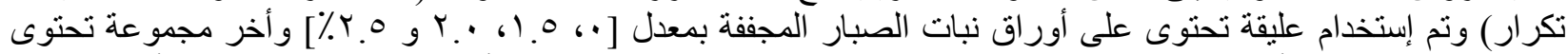

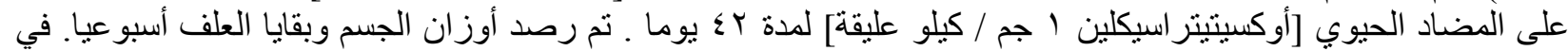

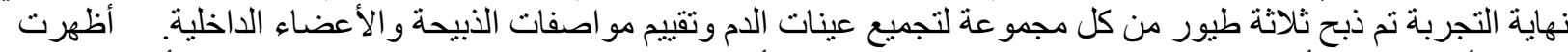

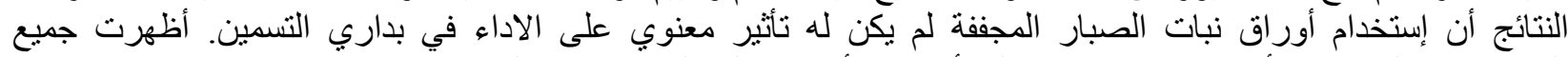

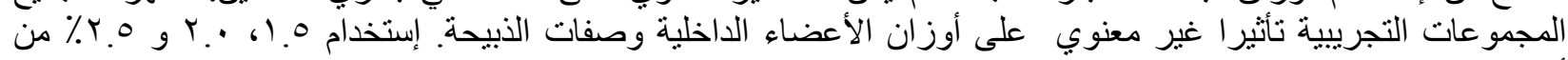

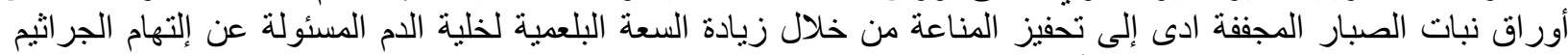

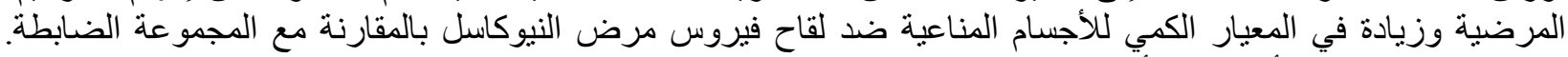

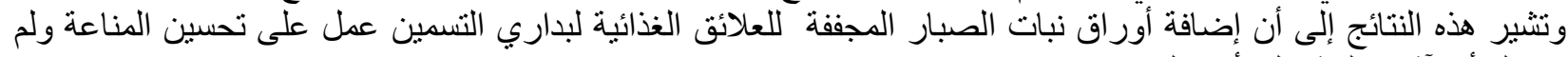
يكن له أي آثار سلبية على أداء النمو. 